\title{
Expression of type I interferon receptor as a predictor of clinical response to interferon- $\alpha$ therapy of gastrointestinal cancers
}

\author{
HIDEO OTA $^{1}$, HIROAKI NAGANO ${ }^{1}$, YUICHIRO DOKI $^{1}$, MITSUGU SEKIMOTO $^{1}$, \\ MOTOI KONDO $^{1}$, HIROSHI WADA $^{1}$, MASATO NAKAMURA $^{1}$, TAKEHIRO NODA ${ }^{1}$, \\ BAZARRAGCHAA DAMDINSUREN $^{1}$, SHIGERU MARUBASHI ${ }^{1}$, ATSUSHI MIYAMOTO ${ }^{1}$, \\ YUTAKA TAKEDA $^{1}$, KEIZO DONO $^{1}$, KOJI UMESHITA ${ }^{1}$, SHOJI NAKAMORI $^{1}$, \\ KENICHI WAKASA ${ }^{2}$, MASATO SAKON ${ }^{1}$ and MORITO MONDEN ${ }^{1}$ \\ ${ }^{1}$ Department of Surgery, Graduate School of Medicine, Osaka University, 2-2 Yamadaoka E-2, Suita, Osaka 565-0871, \\ ${ }^{2}$ Department of Pathology, Osaka City University Hospital, 1-5-7 Asahi-cho, Abeno-ku, Osaka 545-0051, Japan
}

Received February 20, 2006; Accepted March 13, 2006

\begin{abstract}
Interferon (IFN) is used in the treatment of many malignancies and viral disorders. We recently reported a significant correlation between the efficacy of IFN- $\alpha$ combined with chemotherapy in the treatment of advanced hepatocellular carcinoma (HCC) and IFN- $\alpha$ /type I IFN receptor (IFNAR2) expression. It is possible that the expression of IFNAR2 in gastrointestinal cancerous tissue, apart from HCC, may predict the efficacy of IFN- $\alpha$ combination therapy. We investigated the expression of IFNAR2 in 100 gastrointestinal cancerous tissues. IFNAR2 expression was examined using immunohistochemistry, in surgically resected tissue samples (20 esophageal, 20 gastric, 20 colorectal, 20 cholangiocarcinoma, and 20 pancreatic samples). The expression rate of IFNAR2 was $35.0 \%(7 / 20)$, $25.0 \%$ (5/20), $20.0 \%$ (4/20), $45.0 \%$ (9/20), and $25.0 \%(5 / 20)$ in esophageal, gastric cancer, colorectal, cholangiocarcinoma and pancreatic cancer samples, respectively. In our previous report, the expression rate of IFNAR2 in HCC samples was $64.8 \%$ (59/91). Thus, the expression rates of IFNAR2 in the five types of gastrointestinal cancers tested here were low, compared with HCC. The clinical efficacy of IFN- $\alpha$ monoor combination therapies in patients with gastrointestinal
\end{abstract}

Correspondence to: Dr Hiroaki Nagano, Department of Surgery, Graduate School of Medicine, Osaka University, Osaka 565-0871, Japan

E-mail: hnagano@surg2.med.osaka-u.ac.jp

Abbreviations: IFN, interferon; IFNAR2, type I interferon- $\alpha / \beta$ receptor 2; HCC, hepatocellular carcinoma; 5-FU, 5-fluorouracil

Key words: gastrointestinal cancer, IFNAR2, IFN- $\alpha$, therapy, prediction neoplasms is expected to be lower than in patients with HCC based on the expression level of IFNAR2.

\section{Introduction}

Interferon (IFN)- $\alpha$ is used in the treatment of several neoplasms and viral disorders such as chronic myeloid leukemia, hairycell leukemia, adult $\mathrm{T}$ cell leukemia, multiple myeloma, renal cell carcinoma, and chronic hepatitis B and C. For example, Kantarjian et al (1) reported that major cytogenetic responses occurred in $37 \%$ of 148 treated chronic myeloid leukemia patients. Furthermore, the myeloma trialists collaborative groups (2) demonstrated complete and partial responses to IFN monotherapy in $57.5 \%$ of patients with myeloma in meta-analysis study. IFN- $\alpha$ therapy for these diseases is associated with a good prognosis. Based on these findings, IFN- $\alpha$ therapy has been introduced in patients with colorectal cancer. However, Figlin et al (3) reported no responses in 18 patients with colorectal adenocarcinoma, as did Silgals et al (4) in 15 patients with colorectal cancer. However, Eggermont et al (5) reported a $10 \%$ response rate in 10 patients with colorectal cancer. From these reports, it is plausible that IFN- $\alpha$ monotherapy might be effective in patients with colorectal carcinoma. In addition, IFN- $\alpha$ has been used in combination with several anti-cancer agents to enhance the treatment effect. However, this treatment effect was not expected in gastrointestinal cancers and remains controversial, even in colorectal cancer.

IFN- $\alpha$ therapy has also been introduced in hepatocellular carcinoma (HCC). In several randomized controlled trials, IFN- $\alpha$ significantly improved survival in patients with unresectable $\mathrm{HCC}(6,7)$. Moreover, combination therapy with IFN- $\alpha$ has been used for HCC with good efficiency (8-14). In a randomized control trial from Hong Kong, IFN- $\alpha$ treatment was associated with a significant increase in major and minor responses $(22 \%)$ in comparison to doxorubicin (0\%) (15). However, occasional dramatic responses were not seen in 5fluorouracil (5-FU) monotherapy of patients with HCC (16-18). 
(A)

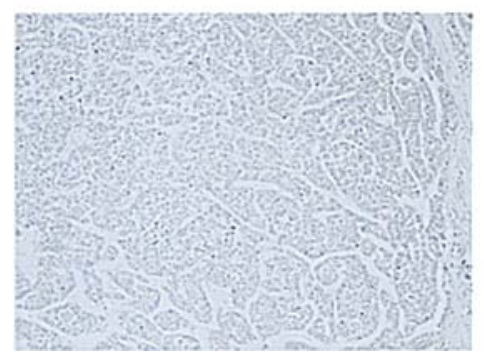

(B)

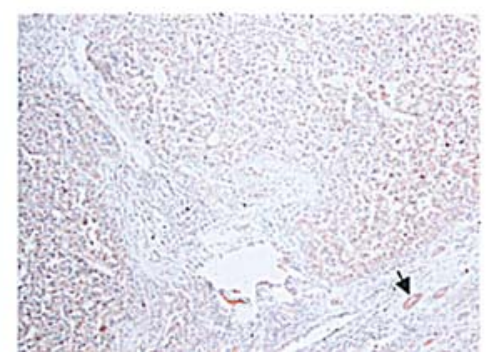

(C)

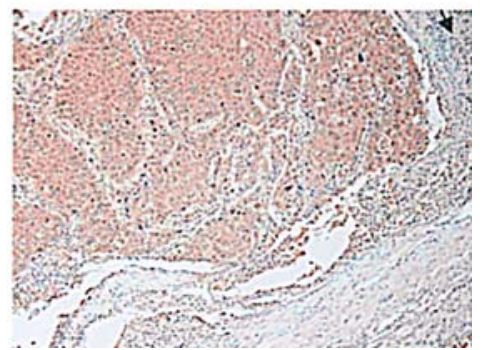

Figure 1. Immunohistochemistry of IFNAR2 expression in HCC tissues as control samples. Representative tissues were used as control samples. The intensity of IFNAR2 was scored on a scale from 0 to 2; 0 , no or faint staining (A); 1, moderate staining (B); and 2, strong staining (C). The latter level of staining was used as an inner control within the sample, which was designated arbitrarily as intensity 1 , because the epithelial cells of the bile ducts generally expressed moderate levels of IFNAR2.

(A)

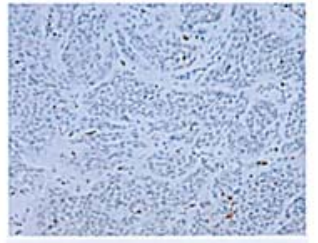

(C)

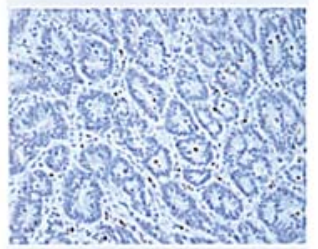

(E)

(G)

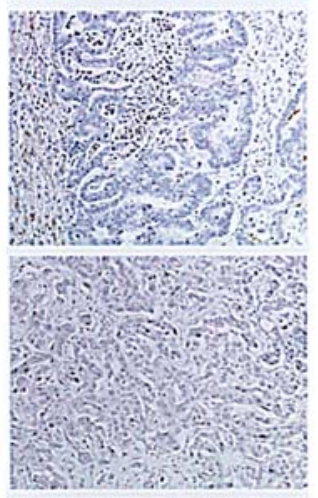

(I)

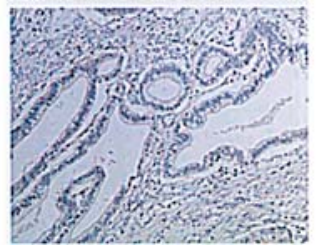

(B)

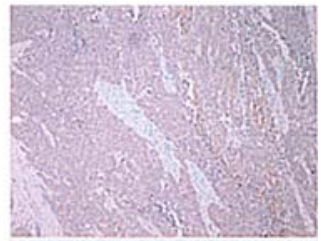

(D)

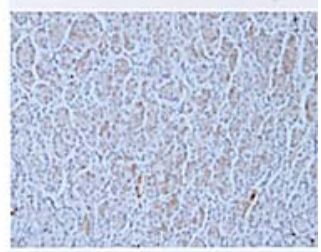

(F)

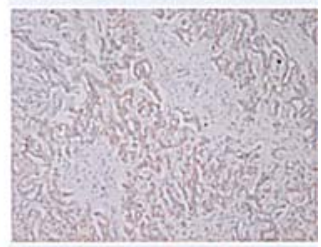

(H)

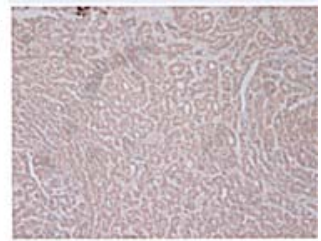

(J)

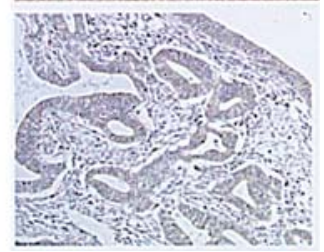

Figure 2. Immunohistochemical analysis of IFNAR2 expression in cancerous tissue. The intensity of IFNAR 2 was scored from 0 to 2 simultaneously with representative tissues of staining intensity of 0 to 2 in HCC. (A, B) Esophageal cancers; intensity 0 (A) and intensity 2 (B). (C, D) Gastric cancers; intensity $0(\mathrm{C})$ and intensity 1 (D). (E, F) Colorectal cancers; intensity 0 (E) and intensity $2(\mathrm{~F}) .(\mathrm{G}, \mathrm{H})$ Cholangiocellular carcinomas; intensity $0,(\mathrm{G})$ and intensity $2(\mathrm{H})$. (I, J) Pancreatic cancers; intensity 0 (I) and intensity 2 (J).

Based on these reports, the clinical use of IFN- $\alpha$ in combination with cytotoxic drugs, such as 5-FU, cisplatin, methotrexate, doxorubicin, may result in beneficial effects in HCC patients.

The mechanism of IFN- $\alpha$ therapy involves binding of IFN- $\alpha$ to type I IFN-receptors (IFNAR1 and IFNAR2 long forms), and binding to the promoter elements of type I IFNinduced genes to initiate their transcription (19-21), resulting in apoptosis. In these signal transduction pathways, IFN receptors play an important role in the treatment of several neoplastic disorders. It thus follows that IFN- $\alpha$ resistance is associated with a lack of IFN receptors. We recently reported that IFNAR2 expression significantly correlates with the effects of IFN- $\alpha / 5$-FU combination therapy in HCC (22). Therefore, the expression of IFNAR2 may be a useful predictive factor for the effect of IFN- $\alpha$ therapy.

In the present study, we investigated the expression of IFNAR2 as a predictive marker for the therapeutic effect of IFN- $\alpha$ on the progression of gastrointestinal cancers.

\section{Materials and methods}

Tumor samples. One hundred surgically resected gastrointestinal cancer samples [20 esophageal, 20 gastric cancer, 20 colorectal (including 9 patients with colorectal liver metastasis), 20 cholangiocarcinoma, and 20 pancreatic] were used in this study. All patients underwent surgery at the Department of Surgery, Osaka University Hospital, between December 1997 and December 2004. Expression of the IFNreceptor was examined by immunohistochemistry. The study protocol was approved by the Human Ethics Review Committee of Osaka University.

Immunohistochemistry. Immunohistochemistry was carried out using the method described in our previous report (23). Tissue sections $(4-\mu \mathrm{m}$ thick) were deparaffinized in xylene and heat antigen retrieval was performed as described previously (23). The slides were then processed for immunohistochemistry on the TechMate Horizon automated staining system (Dako, Glostrup, Denmark) (24), using the EnVision+ peroxidase kit (Dako) (25). In the step of primary antibody reaction, the slides were incubated with the IFNAR2 antibody (final concentration: $2.5 \mathrm{mg} / \mathrm{ml}$ ) (Otsuka Pharmaceutical Co., Tokushima, Japan) overnight at $4^{\circ} \mathrm{C}$. For negative controls, non-immunized rabbit IgG (Vector Laboratories, Burlingame, CA) or Tris buffered saline (TBS) was used as a substitute for the primary antibody to verify the possibility of false positive 
Table I. Expression of IFNAR2 in gastrointestinal cancers.

\begin{tabular}{|c|c|c|c|c|c|c|}
\hline & \multirow{2}{*}{$\begin{array}{l}\text { Number } \\
\text { of cases }\end{array}$} & \multicolumn{3}{|c|}{ Intensity } & \multirow{2}{*}{$\begin{array}{l}\text { Expression } \\
\text { rate }\end{array}$} & \multirow{2}{*}{$\begin{array}{l}\text { Strong expression } \\
\text { rate }\end{array}$} \\
\hline & & 0 & 1 & 2 & & \\
\hline Gastric cancer & 20 & 15 & 5 & 0 & $25.0 \%$ & $0 \%$ \\
\hline Colorectal cancer & 20 & 16 & 3 & 1 & $20.0 \%$ & $5.0 \%$ \\
\hline Cholangiolar carcinoma & 20 & 11 & 8 & 1 & $45.0 \%$ & $5.0 \%$ \\
\hline Pancreatic cancer & 20 & 15 & 3 & 2 & $25.0 \%$ & $10.0 \%$ \\
\hline Hepatocellular carcinoma ${ }^{a}$ & 91 & 32 & 35 & 24 & $64.8 \%$ & $26.4 \%$ \\
\hline
\end{tabular}

${ }^{\mathrm{a} A s}$ previously reported (23).

Table II. Randomized control trials of 5-FU and interferon- $\alpha$ in colorectal cancer.

\begin{tabular}{|c|c|c|c|c|}
\hline Author & Regimen & Dose of 5-fluorouracil & Dose of IFN- $\alpha$ & Response rate \\
\hline Hill et al (33) & 5-FU/LV/IFN- $\alpha$ & $750 \mathrm{mg} / \mathrm{m}^{2}$ i.v. Day $1-5$ & $10 \mathrm{MU} / \mathrm{m}^{2}$ i.m. 3 times/week & $19 \%(10 / 52)$ \\
\hline \multirow[t]{2}{*}{ Kosmidis et al (34) } & 5-FU/LV/IFN- $\alpha$ & $450 \mathrm{mg} / \mathrm{m}^{2}$ i.v. Day $1-5$ & $5 \mathrm{MU} / \mathrm{m}^{2}$ i.m. 3 times/week & $9.8 \%(5 / 53)$ \\
\hline & 5-FU/LV & $450 \mathrm{mg} / \mathrm{m}^{2}$ i.v. Day $1-5$ & - & $7.8 \%(4 / 53)$ \\
\hline \multirow[t]{2}{*}{ Palmeri et al (35) } & $5-\mathrm{FU} / \mathrm{IFN}-\alpha$ & $750 \mathrm{mg} / \mathrm{m}^{2}$ i.v. Day $1-5$ & $3 \mathrm{MU} / \mathrm{m}^{2}$ i.m. 3 times/week & $25 \%(25 / 101)$ \\
\hline & 5-FU alone & $750 \mathrm{mg} / \mathrm{m}^{2}$ i.v. Day $1-5$ & - & $21 \%(22 / 104)$ \\
\hline \multirow[t]{2}{*}{ Hausminger et al (36) } & $5-\mathrm{FU} / \mathrm{LV} / \mathrm{IFN}-\alpha$ & $500 \mathrm{mg} / \mathrm{m}^{2}$ i.v. Day $1-5$ & $7 \mathrm{MU} / \mathrm{m}^{2}$ i.m. 3 times/week & $36 \%(38 / 107)$ \\
\hline & 5-FU/LV & $500 \mathrm{mg} / \mathrm{m}^{2}$ i.v. Day $1-5$ & - & $25 \%(28 / 112)$ \\
\hline & 5-FU/LV & $350 \mathrm{mg} / \mathrm{m}^{2}$ i.v. Day $1-5$ & - & $23 \%(23 / 101)$ \\
\hline
\end{tabular}

5-FU, 5-fluorouracil; LV, leucovorin; IFN, interferon.

responses from non-specific binding of $\mathrm{IgG}$ or from the secondary antibody. In addition, absorption tests were performed on tissue sections. The intensity of IFNAR2 was scored in a scale from 0 to 2 , arbitrarily in $91 \mathrm{HCC}$ samples as reported previously (23). HCC samples including one of no staining (Fig. 1A), one of moderate staining (Fig. 1B) and one of strong staining (Fig. 1C) were used as control samples. All 100 samples with gastrointestinal cancer, except HCC, were evaluated by comparing with these three representative control samples. IFNAR2 expression was often heterogeneous. The histological or immunohistological type that constituted the major volume of the tumor was selected as the representative type. Staining was repeated at least twice to avoid possible technical errors and identical results were obtained. All slides were interpreted by an investigator blinded to the clinical and pathological parameters.

\section{Results}

All 100 samples with gastrointestinal cancers, except HCC, were evaluated by comparison with tissue samples of no staining (Fig. 1A), moderate staining (Fig. 1B), and strong staining in HCC (Fig. 1C) as control samples. In the 20 samples of esophageal cancer, strong expression of IFNAR2 was observed in $5.0 \%(1 / 20)$ of the samples; 1 strongly, 6 moderately, and 13 without or faintly stained (Fig. 2A and B). In the 20 samples of gastric cancer, strong expression of IFNAR2 was observed in $0 \%(0 / 20)$ of the samples; 5 moderately and 15 without or faintly stained (Fig. 2C and D). In the 20 samples of colorectal cancer (including 9 colorectal liver metastasis samples), strong expression of IFNAR2 was observed in $5.0 \%(1 / 20)$ of samples; 1 strongly, 3 moderately, and 16 without or faintly stained (Fig. 2E and F). In the 20 samples of cholangiocellular carcinoma, strong expression of IFNAR2 was observed in $5.0 \%(1 / 20)$ of samples; 1 strongly, 8 moderately, and 11 without or faintly stained (Fig. 2G and $\mathrm{H}$ ). In the 20 samples of pancreatic cancer, strong expression of IFNAR2 was observed in $10.0 \%$ $(2 / 20)$ of samples; 2 strongly, 3 moderately, and 15 without or faintly stained (Fig. 2I and J) (Table I). In comparison, we have previously reported that the expression of IFNAR2 in HCC was observed in $26.4 \%$ (24/91) of the samples; 24 strongly, 35 moderately, and 32 without or faintly stained (23). 
Table III. Interferon- $\alpha$ therapy in gastrointestinal cancers.

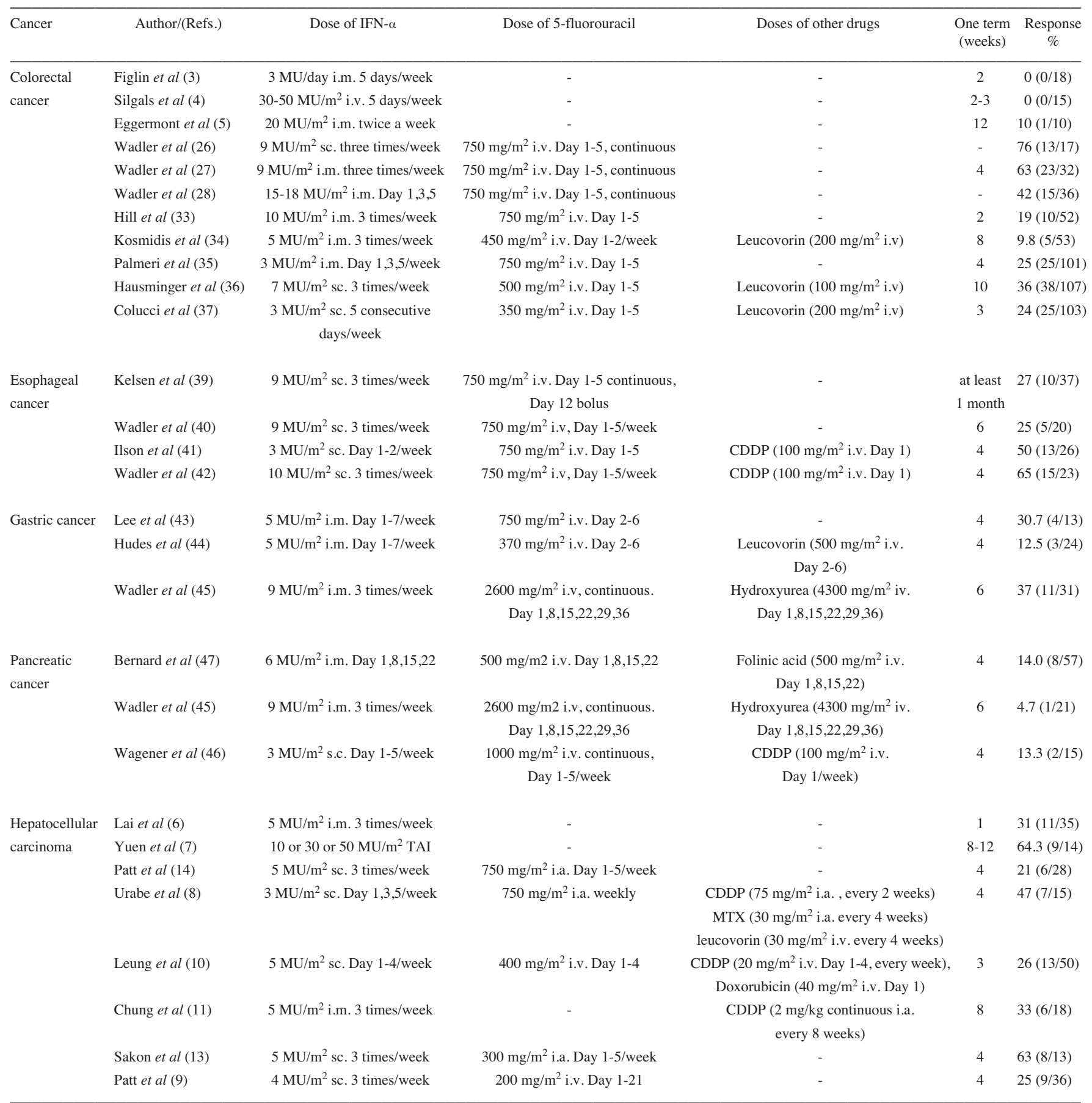

IFN, interferon; 5-FU, 5-fluorouracil; CDDP, cisplatin; MTX, methotrexate.

\section{Discussion}

IFN- $\alpha$ had been proposed to increase the efficacy of 5-FU in many single arm trials of IFN- $\alpha / 5-\mathrm{FU}$ combination therapy for colorectal carcinoma. For example, Wadler et al (26) reported that response rates were $76 \%$ (13/17) in untreated patients with advanced colorectal cancer. In 1990, they indicated that response rates were $63 \%$ in 32 untreated patients with advanced colorectal cancer (27). This combination therapy produced objective responses in 15 of 36 (42\%) patients with colorectal carcinoma in an Eastern Cooperative Oncology
Group (ECOG) study (28). In contrast, 5-FU monotherapy induced objective remissions in only 3 to $25 \%$ of patients with few complete responders, few durable remissions, and no improvement in overall survival (29-32). These results suggest that IFN- $\alpha / 5$-FU combination therapy may generate beneficial effects in colorectal cancer patients (Table II).

However, it was not clear whether IFN- $\alpha$ increases the efficiency of 5-FU in the treatment of colorectal cancer. Therefore, many randomized controlled trials comparing the combination of 5-FU and IFN- $\alpha$ to 5-FU alone have been performed. Hill et al (33) indicated that IFN adds no benefit to 
5-FU in terms of response rates and survival and significantly increases toxicity in patients with advanced colorectal cancer. Kosmidis et al (34) reported that the addition of IFN- $\alpha 2 b$ to the combination of 5-FU and folinic acid contributes to decreased survival. Palmeri et al (35) noted significantly longer survival in patients who achieved a complete response after IFN- $\alpha$ therapy; however, overall survival was not affected. Hausminger et al (36) reported that the addition of IFN to 5-FU/Leucovorin (LV), in schedules and doses used in the present study, did not provide any clinical benefit over 5-FU/LV. Colucci et al (37) reported that no differences in the objective response rate, median duration of response, time to progression, and median survival [comparison between combination of levofolinic acid (1-FA)/5-FU and combination of 1-FA/5-FU/IFN]. In a meta-analysis of these randomized control trials, IFN- $\alpha$ was not found to increase the efficiency of 5-FU in advanced colon cancer (38). Moreover, many therapies combined with IFN- $\alpha$ have been introduced for other gastrointestinal cancers. However, in common with colorectal cancer, the clinical use of IFN- $\alpha$ for other gastrointestinal cancers is doubtful (39-47) (Table III).

Several mechanisms for the anti-cancer effects of IFN- $\alpha$ have been proposed and can be direct and/or indirect antitumor effects. The direct anti-tumor effects include cell damage (48), upregulation of cancer antigens (49), and delayed action on the cell cycle (50). In contrast, indirect anti-tumor actions include activation of natural killer cells (51), T cells (52), and macrophages (53). IFN- $\alpha$ induces cyclin-dependent kinase inhibitors involved in G1/G0 arrest (54). IFN- $\alpha$ may also exert its anti-tumor effect indirectly via the immune system since it is known to augment T-cell cytotoxicity $(55,56)$. Recently, we demonstrated that the modulation of tumor necrosis factorrelated apoptosis-inducing ligand (TRAIL) receptor-mediated cytotoxic pathway might contribute to the anti-HCC effect of IFN- $\alpha / 5$-FU combination therapy (57). Furthermore, IFN- $\alpha$ induces apoptosis of various cancer cells (58). Another possible mechanism of action is via its anti-angiogenesis activity (59).

Based on these anti-tumor mechanisms of IFN- $\alpha$, IFN- $\alpha$ suppressed the proliferation of all IFNAR2-positive cancer cell lines in vitro through mechanisms related to apoptosis or inhibition of the cell cycle (60). The importance of IFNAR2 expression for the anti-cancer effect of IFN- $\alpha$ injection was also reported in our recent studies $(61,62)$. These findings suggest that the anti-neoplastic effects of IFN- $\alpha$ are mediated through IFNAR2. Recently, we found that the expression of IFNAR2 significantly correlates with IFN- $\alpha / 5$-FU combination therapy effects (22) and IFNAR2induced signal transduction was useful for molecular prediction of the response to IFN- $\alpha / 5$-FU combination therapy in advanced HCC (63). Therefore, this significant relationship demonstrated in HCC should be also present in other gastrointestinal cancers. Accordingly, we investigated IFNAR2 expression in various gastrointestinal cancers using immunohistochemistry, as described in our previous report (23). The expression rate of IFNAR2 was not high in gastrointestinal cancers, in comparison with our previous results in HCC. We previously reported a strong expression rate of IFNAR2, at $26.4 \%$ (35/91), in HCC (23). The results of the present study indicate that the strong expression rate of
IFNAR2 in gastrointestinal cancers, excluding HCC, was within $10 \%$ and lower than that in HCC. Based on these results, we believe that the efficiency of combination therapy with IFN- $\alpha$ in these cancers is expected be lower than that in HCC.

These results were compatible with those reported by Ambrus et al (64). They reported that all patients had increased levels of free interferon receptor- $\alpha / \beta$ type-I in the circulation, with the highest levels reported in patients with adenocarcinoma. High IFN inhibitory activity in patients with cancer may be a significant factor in their increased susceptibility to progressive disease. These soluble forms can be both agonists and antagonists, depending on their concentration (65), and high levels of circulating soluble IFN receptors may block the anti-proliferative activity of IFN- $\alpha$ in adenocarcinomas.

In summary, we demonstrated that IFNAR2 expression rates in esophageal, gastric, colorectal, and pancreatic cancers and cholangiocarcinoma were lower than in HCC. Compared with our recent investigation in HCC, the clinical efficacy of IFN- $\alpha$ in combination therapies with other cytotoxic drugs in these gastrointestinal cancers is expected to be lower than that in HCC. To increase the treatment efficacy of IFN for gastrointestinal cancers other than HCC, other treatment modalities should be included, such as IFNAR2 gene transfection (66) or IFN-based chemoradiation (67).

\section{Acknowledgements}

The authors thank Dr Yasukazu Ohmoto from the First Institute of New Drug Research, and Otsuka Pharmaceutical Co., Ltd., for providing anti-human IFNAR2 antibody (OCT4813). The authors gratefully acknowledge Mrs. Satomi Yamane for her excellent technical assistance. This work was supported by a Grant-in-Aid for cancer research from the Ministry of Education, Culture and Science of Japan.

\section{References}

1. Kantarjian HM, O'Brien S, Cortes JE, Shan J, Giles FJ, Rios MB, Faderl SH, Wierda WG, Ferrajoli A, Verstovsek S, Keating MJ, Freireich EJ and Talpaz M: Complete cytogenetic and molecular responses to interferon-alpha-based therapy for chronic myelogenous leukemia are associated with excellent long-term prognosis. Cancer 97: 1033-1041, 2003.

2. Interferon as therapy for multiple myeloma: an individual patient data overview of 24 randomized trials and 4012 patients. Br J Haematol 113: 1020-1034, 2001.

3. Figlin RA, Callaghan M and Sarna G: Phase II trial of alpha (human leukocyte) interferon administered daily in adenocarcinoma of the colon/rectum. Cancer Treat Rep 67: 493-494, 1983 .

4. Silgals RM, Ahlgren JD, Neefe JR, Rothman J, Rudnick S, Galicky FP and Schein PS: A Phase II trial of high-dose intravenous interferon alpha- 2 in advanced colorectal cancer. Cancer 54: 2257-2261, 1984.

5. Eggermont AM, Weimar W, Tank B, Dekkers-Bijma AM, Marquet RL, Lameris JS, Westbroek DL and Jeekel J: Clinical and immunological evaluation of 20 patients with advanced colorectal cancer treated with high dose recombinant leukocyte interferon-alpha A (rIFN alpha A). Cancer Immunol Immunother 21: 81-84, 1986 .

6. Lai CL, Lau JY, Wu PC, Ngan H, Chung HT, Mitchell SJ, Corbett TJ, Chow AW and Lin HJ: Recombinant interferonalpha in inoperable hepatocellular carcinoma: a randomized controlled trial. Hepatology 17: 389-394, 1993. 
7. Yuen MF, Ooi CG, Hui CK, Wong WM, Wong BC, Chan AO and Lai CL: A pilot study of transcatheter arterial interferon embolization for patients with hepatocellular carcinoma. Cancer 97: 2776-2782, 2003

8. Urabe T, Kaneko S, Matsushita E, Unoura M and Kobayashi K: Clinical pilot study of intrahepatic arterial chemotherapy with methotrexate, 5-fluorouracil, cisplatin and subcutaneous interferon-alpha-2b for patients with locally advanced hepatocellular carcinoma. Oncology 55: 39-47, 1998

9. Patt YZ, Hassan MM, Lozano RD, Brown TD, Vauthey JN, Curley SA and Ellis LM: Phase II trial of systemic continuous fluorouracil and subcutaneous recombinant interferon Alfa- $2 \mathrm{~b}$ for treatment of hepatocellular carcinoma. J Clin Oncol 21: 421-427, 2003.

10. Leung TW, Patt YZ, Lau WY, Ho SK, Yu SC, Chan AT, Mok TS, Yeo W, Liew CT, Leung NW, Tang AM and Johnson PJ: Complete pathological remission is possible with systemic combination chemotherapy for inoperable hepatocellular carcinoma. Clin Cancer Res 5: 1676-1681, 1999.

11. Chung YH, Song IH, Song BC, Lee GC, Koh MS, Yoon HK, Lee YS, Sung KB and Suh DJ: Combined therapy consisting of intraarterial cisplatin infusion and systemic interferon-alpha for hepatocellular carcinoma patients with major portal vein thrombosis or distant metastasis. Cancer 88: 1986-1991, 2000.

12. Miyamoto A, Umeshita K, Sakon M, Nagano H, Eguchi $H$, Kishimoto S, Dono K, Nakamori S, Gotoh M and Monden M: Advanced hepatocellular carcinoma with distant metastases, successfully treated by a combination therapy of alpha-interferon and oral tegafur/uracil. J Gastroenterol Hepatol 15: 1447-1451, 2000.

13. Sakon M, Nagano H, Dono K, Nakamori S, Umeshita K, Yamada A, Kawata S, Imai Y, Iijima S and Monden M: Combined intraarterial 5-fluorouracil and subcutaneous interferon-alpha therapy for advanced hepatocellular carcinoma with tumor thrombi in the major portal branches. Cancer 94: 435-442, 2002

14. Patt YZ, Yoffe B, Charnsangavej C, Pazdur R, Fischer H, Cleary K, Roh M, Smith R, Noonan CA and Levin B: Low serum alpha-fetoprotein level in patients with hepatocellular carcinoma as a predictor of response to 5-FU and interferon-alpha-2b. Cancer 72: 2574-2582, 1993

15. Lai CL, Wu PC, Lok AS, Lin HJ, Ngan H, Lau JY, Chung HT, Ng MM, Yeoh EK and Arnold M: Recombinant alpha 2 interferon is superior to doxorubicin for inoperable hepatocellular carcinoma: a prospective randomised trial. Br J Cancer 60: 928-933, 1989.

16. Link JS, Bateman JR, Paroly WS, Durkin WJ and Peters RL: 5-Flourouracil in hepatocellular carcinoma: report of twenty-one cases. Cancer 39: 1936-1939, 1977.

17. Doci R, Bignami P, Bozzetti F, Bonfanti G, Audisio R, Colombo $\mathrm{M}$ and Gennari L: Intrahepatic chemotherapy for unresectable hepatocellular carcinoma. Cancer 61: 1983-1987, 1988.

18. Tokyo Liver Cancer Chemotherapy Study Group: Phase II study of co-administration of uracil and tegafur (UFT) in hepatocellular carcinoma. Jpn J Clin Oncol 15: 559-562, 1985.

19. Taniguchi T: Cytokine signaling through nonreceptor protein tyrosine kinases. Science 268: 251-255, 1995.

20. Pestka S: The interferon receptors. Semin Oncol 24: S9-S40, 1997.

21. Hoey $\mathrm{T}$ and Schindler U: STAT structure and function in signaling. Curr Opin Genet Dev 8: 582-587, 1998

22. Ota H, Nagano H, Sakon M, Eguchi H, Kondo M, Yamamoto T, Nakamura M, Damdinsuren B, Wada H, Marubashi S, Miyamoto A, Dono K, Umeshita K, Nakamori S, Wakasa K and Monden M: Treatment of hepatocellular carcinoma with major portal vein thrombosis by combined therapy with subcutaneous interferon-alpha and intra-arterial 5-fluorouracil; role of type 1 interferon receptor expression. Br J Cancer 93: 557-564, 2005.

23. Kondo M, Nagano H, Sakon M, Yamamoto H, Morimoto O, Arai I, Miyamoto A, Eguchi H, Dono K, Nakamori S, Umeshita K, Wakasa K, Ohmoto Y and Monden M: Expression of interferon alpha/beta receptor in human hepatocellular carcinoma. Int J Oncol 17: 83-88, 2000.

24. Ciaparrone M, Yamamoto H, Yao Y, Sgambato A, Cattoretti G, Tomita N, Monden T, Rotterdam H and Weinstein IB Localization and expression of p27KIP1 in multistage colorectal carcinogenesis. Cancer Res 58: 114-122, 1998.

25. Short BG, Zimmerman DM and Schwartz LW: Automated double labeling of proliferation and apoptosis in glutathione $\mathrm{S}$-transferase-positive hepatocytes in rats. J Histochem Cytochem 45: 1299-1305, 1997.
26. Wadler S, Schwartz EL, Goldman M, Lyver A, Rader M, Zimmerman M, Itri L, Weinberg V and Wiernik PH: Fluorouracil and recombinant alfa-2a-interferon: an active regimen against advanced colorectal carcinoma. J Clin Oncol 7: 1769-1775, 1989.

27. Wadler S, Goldman M, Lyver A and Wiernik PH: Phase I trial of 5-fluorouracil and recombinant alpha 2a-interferon in patients with advanced colorectal carcinoma. Cancer Res 50: 2056-2059, 1990.

28. Wadler S, Lembersky B, Atkins M, Kirkwood J and Petrelli N: Phase II trial of fluorouracil and recombinant interferon alfa-2a in patients with advanced colorectal carcinoma: an Eastern Cooperative Oncology Group study. J Clin Oncol 9: 1806-1810, 1991

29. Comparison of antimetabolites in the treatment of breast and colon cancer. JAMA 200: 770-778, 1967.

30. Carter SK: Editorial: Large-bowel cancer - The current status of treatment. J Natl Cancer Inst 56: 3-10, 1976.

31. Davis HL: Chemotherapy of large bowel cancer. Cancer 50: 2638-2646, 1982.

32. Ansfield F, Klotz J, Nealon T, Ramirez G, Minton J, Hill G, Wilson W, Davis H Jr and Cornell G: A phase III study comparing the clinical utility of four regimens of 5-fluorouracil: a preliminary report. Cancer 39: 34-40, 1977.

33. Hill M, Norman A, Cunningham D, Findlay M, Nicolson V, Hill A, Iveson A, Evans C, Joffe J, Nicolson M, et al: Royal Marsden phase III trial of fluorouracil with or without interferon alfa-2b in advanced colorectal cancer. J Clin Oncol 13: 1297-1302, 1995.

34. Kosmidis PA, Tsavaris N, Skarlos D, Theocharis D, Samantas E, Pavlidis N, Briassoulis E and Fountzilas G: Fluorouracil and leucovorin with or without interferon alfa- $2 b$ in advanced colorectal cancer: analysis of a prospective randomized phase III trial. Hellenic Cooperative Oncology Group. J Clin Oncol 14: 2682-2687, 1996.

35. Palmeri S, Meli M, Danova M, Bernardo G, Leonardi V, Dastoli G, Rausa L, Russo A, Filippelli G, Palmieri G, Della Vittoria Scarpati M, Lo Russo V, Di Lauro L, Colucci G, Bruni G, Piazzi M, Gebbia N and Spada S: 5-Fluorouracil plus interferon alpha-2a compared to 5-fluorouracil alone in the treatment of advanced colon carcinoma: a multicentric randomized study. J Cancer Res Clin Oncol 124: 191-198, 1998.

36. Hausmaninger H, Moser R, Samonigg H, Mlineritsch B, Schmidt H, Pecherstorfer M, Fridrik M, Kopf C, Nitsche D, Kaider A and Ludwig H: Biochemical modulation of 5fluorouracil by leucovorin with or without interferon-alpha-2c in patients with advanced colorectal cancer: final results of a randomised phase III study. Eur J Cancer 35: 380-385, 1999

37. Colucci G, Maiello E, Gebbia V, Giuliani F, Serravezza G, Lelli G, Leo S, Filippelli G, Nicolella G and Brandi M: 5-Fluorouracil and levofolinic acid with or without recombinant interferon- $2 b$ in patients with advanced colorectal carcinoma: a randomized multicenter study with stratification for tumor burden and liver involvement by the Southern Italy Oncology Group. Cancer 85: 535-545, 1999.

38. Thirion P, Piedbois P, Buyse M, O'Dwyer PJ, Cunningham D, Man A, Greco FA, Colucci G, Kohne CH, Di Constanzo F, Piga A, Palmeri S, Dufour P, Cassano A, Pajkos G, Pensel RA, Aykan NF, Marsh J and Seymour MT: Alpha-interferon does not increase the efficacy of 5-fluorouracil in advanced colorectal cancer. Br J Cancer 84: 611-620, 2001.

39. Kelsen D, Lovett D, Wong J, Saltz L, Buckley M, Murray P, Heelan R and Lightdale C: Interferon alfa-2a and fluorouracil in the treatment of patients with advanced esophageal cancer. J Clin Oncol 10: 269-274, 1992.

40. Wadler S, Fell S, Haynes H, Katz HJ, Rozenblit A, Kaleya R and Wiernik PH: Treatment of carcinoma of the esophagus with 5-fluorouracil and recombinant alfa-2a-interferon. Cancer 71: 1726-1730, 1993.

41. Ilson DH, Sirott M, Saltz L, Heelan R, Huang Y, Keresztes R and Kelsen DP: A phase II trial of interferon alpha-2A, 5fluorouracil, and cisplatin in patients with advanced esophageal carcinoma. Cancer 75: 2197-2202, 1995.

42. Wadler S, Haynes H, Beitler JJ, Hu X, Fell S, Camacho M, Levine B and Wiernik PH: Phase II clinical trial with 5fluorouracil, recombinant interferon-alpha-2b, and cisplatin for patients with metastatic or regionally advanced carcinoma of the esophagus. Cancer 78: 30-34, 1996.

43. Lee KH, Lee JS, Suh C, Lee YS, Min YI, Ahn SH, Park KC, Kim SK and Kim SH: Combination of 5-fluorouracil and recombinant interferon alpha-2B in advanced gastric cancer. A phase I study. Am J Clin Oncol 15: 141-145, 1992. 
44. Hudes GR, Lipsitz S, Grem J, Morrisey M, Weiner L, Kugler JW and Benson A III: A phase II study of 5-fluorouracil, leucovorin, and interferon-alpha in the treatment of patients with metastatic or recurrent gastric carcinoma: an Eastern Cooperative Oncology Group study (E5292). Cancer 85: 290-294, 1999.

45. Wadler S, Damle S, Haynes H, Kaleya R, Schechner R, Berkenblit R, Ladner RD and Murgo A: Phase II/pharmacodynamic trial of dose-intensive, weekly parenteral hydroxyurea and fluorouracil administered with interferon alfa- $2 \mathrm{a}$ in patients with refractory malignancies of the gastrointestinal tract. J Clin Oncol 17: 1771-1778, 1999.

46. Wagener DJ, Wils JA, Kok TC, Planting A, Couvreur ML and Baron B: Results of a randomised phase II study of cisplatin plus 5-fluorouracil versus cisplatin plus 5-fluorouracil with alphainterferon in metastatic pancreatic cancer: an EORTC gastrointestinal tract cancer group trial. Eur J Cancer 38: 648-653, 2002.

47. Bernhard H, Jager-Arand E, Bernhard G, Heike M, Klein O, Riemann JF, Meyer zum Buschenfelde KH, Dippold W and Knuth A: Treatment of advanced pancreatic cancer with 5fluorouracil, folinic acid and interferon alpha-2A: results of a phase II trial. Br J Cancer 71: 102-105, 1995.

48. Grander D, Xu B and Einhorn S: Cytotoxic effect of interferon on primary malignant tumour cells. Studies in various malignancies. Eur J Cancer 29A: 1940-1943, 1993.

49. Guadagni F, Schlom J, Johnston WW, Szpak CA, Goldstein D, Smalley R, Simpson JF, Borden EC, Pestka S and Greiner JW: Selective interferon-induced enhancement of tumor-associated antigens on a spectrum of freshly isolated human adenocarcinoma cells. J Natl Cancer Inst 81: 502-512, 1989.

50. Kimchi A: Cytokine triggered molecular pathways that control cell cycle arrest. J Cell Biochem 50: 1-9, 1992.

51. Ortaldo JR, Mantovani A, Hobbs D, Rubinstein M, Pestka S and Herberman RB: Effects of several species of human leukocyte interferon on cytotoxic activity of NK cells and monocytes. Int J Cancer 31: 285-289, 1983.

52. Brinkmann V, Geiger T, Alkan S and Heusser CH: Interferon alpha increases the frequency of interferon gamma-producing human CD4+ T cells. J Exp Med 178: 1655-1663, 1993.

53. Uno K, Shimizu S, Ido M, Naito K, Inaba K, Oku T, Kishida $T$ and Muramatsu S: Direct and indirect effects of interferon on in vivo murine tumor cell growth. Cancer Res 45: 1320-1327, 1985.

54. Sangfelt O, Erickson S, Castro J, Heiden T, Gustafsson A, Einhorn S and Grander D: Molecular mechanisms underlying interferon-alpha-induced G0/G1 arrest: CKI-mediated regulation of G1 Cdk-complexes and activation of pocket proteins. Oncogene 18: 2798-2810, 1999.

55. Trinchieri G, Santoli D and Koprowski H: Spontaneous cellmediated cytotoxicity in humans: role of interferon and immunoglobulins. J Immunol 120: 1849-1855, 1978.

56. Lindahl P, Leary P and Gresser I: Enhancement by interferon of the specific cytotoxicity of sensitized lymphocytes. Proc Natl Acad Sci USA 69: 721-725, 1972.
57. Yamamoto T, Nagano H, Sakon M, Wada H, Eguchi H, Kondo M, Damdinsuren B, Ota H, Nakamura M, Marubashi S, Miyamoto A, Dono K, Umeshita K, Nakamori S, Yagita H and Monden M: Partial contribution of tumor necrosis factor-related apoptosisinducing ligand (TRAIL)/TRAIL receptor pathway to antitumor effects of interferon-alpha/5-fluorouracil against hepatocellular carcinoma. Clin Cancer Res 10: 7884-7895, 2004.

58. Horowitz RW, Heerdt BG, Hu X, Schwartz EL and Wadler S: Combination therapy with 5-fluorouracil and IFN-alpha2a induces a nonrandom increase in DNA fragments of less than 3 megabases in HT29 colon carcinoma cells. Clin Cancer Res 3: 1317-1322, 1997

59. Folkman $J$ and Ingber D: Inhibition of angiogenesis. Semin Cancer Biol 3: 89-96, 1992.

60. Yano H, Iemura A, Haramaki M, Ogasawara S, Takayama A, Akiba $J$ and Kojiro M: Interferon alfa receptor expression and growth inhibition by interferon alfa in human liver cancer cell lines. Hepatology 29: 1708-1717, 1999.

61. Kondo M, Nagano H, Wada H, Damdinsuren B, Yamamoto H, Hiraoka N, Eguchi H, Miyamoto A, Yamamoto T, Ota H, Nakamura M, Marubashi S, Dono K, Umeshita K, Nakamori S, Sakon M and Monden M: Combination of IFN-alpha and 5fluorouracil induces apoptosis through IFN-alpha/beta receptor in human hepatocellular carcinoma cells. Clin Cancer Res 11: $1277-1286,2005$

62. Eguchi H, Nagano H, Yamamoto H, Miyamoto A, Kondo M, Dono K, Nakamori S, Umeshita K, Sakon M and Monden M: Augmentation of antitumor activity of 5-fluorouracil by interferon alpha is associated with up-regulation of p27Kip1 in human hepatocellular carcinoma cells. Clin Cancer Res 6: 2881-2890, 2000

63. Kurokawa Y, Matoba R, Nagano H, Sakon M, Takemasa I, Nakamori S, Dono K, Umeshita K, Ueno N, Ishii S, Kato K and Monden M: Molecular prediction of response to 5-fluorouracil and interferon-alpha combination chemotherapy in advanced hepatocellular carcinoma. Clin Cancer Res 10: 6029-6038, 2004.

64. Ambrus JL Sr, Dembinski W, Ambrus JL Jr, Sykes DE, Akhter S, Kulaylat MN, Islam A and Chadha KC: Free interferonalpha/beta receptors in the circulation of patients with adenocarcinoma. Cancer 98: 2730-2733, 2003.

65. Hardy MP, Owczarek CM, Trajanovska S, Liu X, Kola I and Hertzog PJ: The soluble murine type I interferon receptor Ifnar-2 is present in serum, is independently regulated, and has both agonistic and antagonistic properties. Blood 97: 473-482, 2001.

66. Wagner TC, Velichko S, Chesney SK, Biroc S, Harde D, Vogel D and Croze E: Interferon receptor expression regulates the antiproliferative effects of interferons on cancer cells and solid tumors. Int J Cancer 111: 32-42, 2004.

67. Takaoka A, Hayakawa S, Yanai H, Stoiber D, Negishi H, Kikuchi H, Sasaki S, Imai K, Shibue T, Honda K and Taniguchi T: Integration of interferon-alpha/beta signalling to p53 responses in tumour suppression and antiviral defence. Nature 424: 516-523, 2003. 